\title{
ASSESSMENT OF MEDICAL STUDENTS' METACOGNITIVE AWARENESS OF READING STRATEGIES AND ITS RELATION WITH ACADEMIC PERFORMANCE: A CROSS SECTIONAL STUDY AT AZIZ FATIMA MEDICAL AND DENTAL COLLEGE, FAISALABAD.
}

\author{
Subhan Ullah ${ }^{\mathrm{a}}$, Sami Ullah ${ }^{\mathrm{b}}$, Khalid Parvez ${ }^{ }$, Ghulam Abbas Sheikh ${ }^{\mathrm{d}}$ \\ ${ }^{a}$ Senior Registrar Psychiatry, Head Department of Psychiatry and Behavioral Sciences, Aziz Fatima Medical \\ College, Faisalabad, Pakistan. \\ ${ }^{\mathrm{b}}$ Medical Officer, Allied Hospital Faisalabad Medical University, Faisalabad. \\ ${ }^{\mathrm{c}}$ Assistant Professor of Rheumatology, Faisalabad Medical University, Faisalabad. \\ ${ }^{\mathrm{d}}$ Professor of Medicine, Department of Medicine, Aziz Fatima Medical College, Faisalabad, Pakistan.
}

\begin{abstract}
:
BACKGROUND \& OBJECTIVE: Students reading strategies strongly influence their academic performance. Our study aimed to determine medical students' metacognitive awareness during reading strategies and its relation with their academic scores.

METHODOLOGY: Study was done among third year MBBS students of Aziz Fatima Medical College Faisalabad. Students previous years academic achievement information was collected and they also filled questionnaire on metacognition regulation by the Metacognitive Awareness Reading Strategies Inventory. Convenient sampling was used for this study. The data were analyzed in SPSS 20. In our study the independent variable was metacognitive score while previous professional examination marks were taken as the dependent variable.Standard deviation and mean were used for the descriptive data. For categorical data, percentage and frequencies were used.

RESULTS:

Different reading strategies employed by medical students in relation to metacognition were our main focus in the study. Metacognition was taken as score measured by a 30 item MARSI scale and their academic performance measured in terms of total marks obtained in the last professional examination held by the University. Total 101 out of 110 students from 3rd year MBBS class were enrolled in the study and the response rate was $92 \%$. Forty one (41) respondents were females and sixty $(60)$ respondents were male the mean \pm SD age of students was $21.05 \pm 0.74$.

CONCLUSION: All dimensions of metacognition are positive and strongly correlated with each other's. Higher the score in one dimension will cause positive change in other dimension score and vice versa.

KEYWORDS: Metacognition, Metacognition awareness, Medical students, Academic achievement, Reading strategies.
\end{abstract}

How to cite this:

doi: https://doi.org/10.37723/jumdc.v11i3.445

Ullah S, Ullah S, Parvez K, Sheikh GA. ASSESSMENT OF MEDICAL STUDENTS' METACOGNITIVE AWARENESS OF READING STRATEGIES AND ITS RELATION WITH ACADEMIC PERFORMANCE: A CROSS SECTIONAL STUDY AT AZIZ FATIMA MEDICAL AND DENTAL COLLEGE, FAISALABAD. jumdc. 2020;11(3):1-8.

doi: https://doi.org/10.37723/jumdc.v11i3.445

This is an Open Access article distributed under the terms of the Creative Commons Attribution License (http://creativecommons.org/licenses/by/4.0), which permits unrestricted use, distribution, and reproduction in any medium, provided the original work is properly cited. 


\section{INTRODUCTION:}

The concept of metacognition is gaining immense importance in contemporary medical field because of its long lasting impact on medical education and student's performance. Metacognition is one of the subtypes of cognition and it is usually described as a person's thinking or a set of processes an individual uses in monitoring ongoing cognition to control his or her own behavior ${ }^{[1]}$. The concept was first described by Flavell and is regarded as the activity of monitoring and controlling one's thinking, reading and doing actions and using this cognitive process to learn and remember ${ }^{[2]}$. In medical school reading books is related to success. The complex process of reading uses interplay of different linguistic as well as cognitive and perceptual abilities. Student's reflections about reading medical books are examined to understand what they think and do when reading.

These reflections often reveal what kind of judgments students hold about their own reading processes and they are usually known as conventional descriptions of metacognition. Metacognitive reading strategies and reading motivation play a significant role in reading comprehension ${ }^{[3]}$. They give us valuable information how they are monitoring, evaluating and planning and making a sense of what they are reading. Reading strategies are made up of different cognitive processes readers employ to analyze a text. Contemporary research indicated that metacognitive beliefs and self-regulating strategies have effect on students' academic achievement ${ }^{[4]}$. Researchers have been recognizing the importance of metacognition in medical students reading comprehension because it differentiates between skilled and unskilled readers. Efficient or strategic readers carefully manipulate cognitive resources when reading ${ }^{[5]}$. Skilled readers are good comprehends ${ }^{[6]}$. Medical Students who are good at reading books usually connect what they are reading right now with their previous knowledge, and they can tell what may be coming next. At the end of session they can sum up the whole reading experience. Metacognition has a role in understanding and supporting reading comprehension ${ }^{[7]}$.

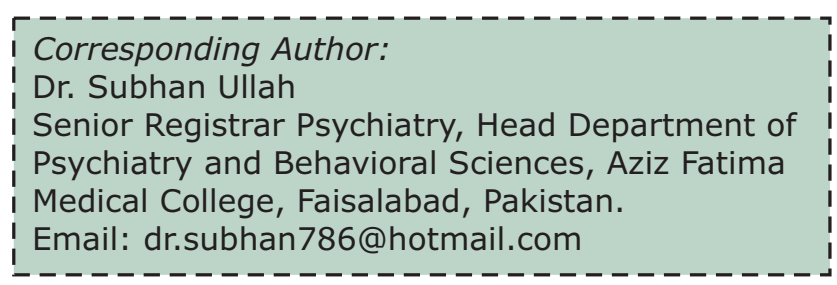

These comprehension strategies are metacognitive concepts in reading. It is important to plan, monitor and evaluate the reading process when we read or before it and are included in metacognitive reading strategies. The mediating role of metacognition on comprehension and reading strategies is established by the research ${ }^{[8]}$.

Metacognition has two main components, first is metacognition awareness and second is metacognition regulation ${ }^{[9]}$.

In medical education the metacognition is related to reading processes and could be used to predict learning and educational performance. Metacognitive understanding is strongly related with academic outcome of the medical students ${ }^{[10]}$. Medical students have different reading patterns which strongly influences educational achievement. Good readers have ability to draw on a variety of strategies in a coherent manner to process reading texts ${ }^{[7]}$.

Our study was aimed at assessing whether students were aware of the different mental processes while reading and to know about what they are thinking and doing while reading to cope with stress of academic reading tasks. This study will be useful for medical students to improve their metacognitive skills and to perform better in academic activities and help policymakers in making better policies.

\section{METHODOLOGY:}

We designed descriptive cross sectional study and conducted it among 3rd-year MBBS students in Aziz Fatima Medical College Faisalabad from $1^{\text {st }}$ June to $31^{\text {st }}$ July-2020. The study has been approved by the ethical review committee of Aziz Fatima Medical Dental College. To assess metacognitive score, we used Metacognitive Awareness of Reading Strategies Inventory (MARSI) (Version 1.0) by Mokhtari $\mathrm{K}^{[11]}$. Value of Cronbach's Alpha was 0.73 it is also called reliability coefficient. For 
academic performance, we obtained the marks of the students in the last University Professional examination from the student's affairs department of the college.

This is a very useful inventory for researchers and the data collected can be used to monitor students' progress in reading, estimating scheduling, and regulation of the knowledge. Thirty (30) items in the inventory were designed to measure the metacognition. In different countries this instrument has met with satisfactory results. Validity and reliability of the inventory is also very well-known ${ }^{[12,13]}$.

We choose this inventory for our students because it was easy to understand. The MARSI Questionnaire measures three reading strategies:

1. Global Reading Strategies (GLOB SCORE): 13 items are specified for it and it reflects a global analysis of the reading text.

2. Problem-Solving Strategies (PROB SCORE): It is specified by 8 items in the questionnaire it is oriented towards problem solving tasks when students feel difficulty in reading medical books.

3. Support Reading Strategies (SUP SCORE): It is checked by 9 items and include use of strategies that are called functional or support strategies

It was conducted during online classroom. The purpose of the study was explained as well as a description of the instrument was given with steps involved in completing it. We instructed the students to read statements and mark the number using a Likert scale which match their own use of the strategy. The responses were not categorized as right or wrong and students could take 20 minutes time to complete. Third year MBBS students who were present on the day of data collection were encouraged to enroll for study purpose.

\section{RESULTS:}

In this study we focused on the metacognitive reading strategies of the medical students as measured by 30 item MARSI scale and their academic performance measured in terms of total marks obtained in the last professional examination held by the University. Total 101 out of 110 students from 3rd year MBBS class were enrolled in the study and the response rate was $92 \%$. In our study, 41 respondents were females and 60 respondents were male.The demographic data of the students who participated in the study are given in Table-1. The data has been represented in the frequency and percentage. Quantitative variables of the study are drawn in Figure-2 through multiple Bar Charts. The mean \pm SD age of students was $21.05 \pm 0.74$

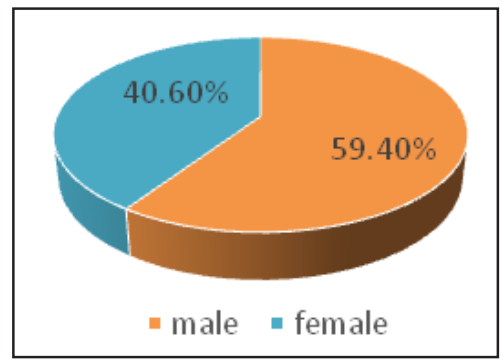

Figure-I: Gender distribution of participants.

Table-I: Demographic Characteristics of the Sample $(n=101)$.

\begin{tabular}{|c|c|c|}
\hline Variable & $\mathbf{F}$ & $\%$ \\
\hline \multicolumn{3}{|l|}{ Gender } \\
\hline Female & 41 & 40.6 \\
\hline Male & 60 & 59.4 \\
\hline \multicolumn{3}{|l|}{ Location } \\
\hline Rural & 8 & 7.1 \\
\hline Urban & 93 & 92.9 \\
\hline \multicolumn{3}{|l|}{ Residence } \\
\hline Day Scholar & 82 & 81.2 \\
\hline Hostelites & 19 & 18.8 \\
\hline \multicolumn{3}{|c|}{ Family System } \\
\hline Joint & 37 & 36.6 \\
\hline Single & 64 & 63.4 \\
\hline \multicolumn{3}{|c|}{ Father Occupation } \\
\hline Business man & 32 & 31.7 \\
\hline Teacher & 13 & 12.9 \\
\hline Private Job & 5 & 5.0 \\
\hline Doctor & 9 & 8.9 \\
\hline Others & 8 & 7.9 \\
\hline
\end{tabular}




\section{Description of quantitative variables of study}
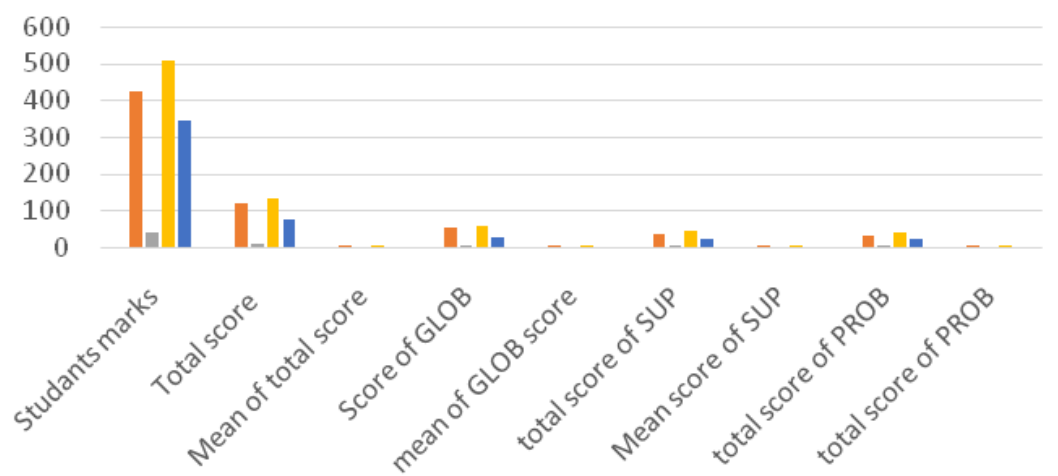

- Mean $\square$ SD Maximum Minimum

Figure-II: Multi bar Chart Description of Quantitative variables of study.

Table-II: Pearson Product-moment Correlation between strategy subcategories of metacognition $(n=101)$.

\begin{tabular}{|c|c|c|c|c|}
\hline Variable & & GLOB Score & $\begin{array}{c}\text { PROB } \\
\text { Score }\end{array}$ & SUB Score \\
\hline \multirow{2}{*}{$\begin{array}{c}\text { GLOB SCORE } \\
\text { Global Reading Strategies) }\end{array}$} & Pearson correlation & 1 & $0.216^{* *}$ & $0.319^{* *}$ \\
\cline { 2 - 5 } & p-value & - & 0.030 & 0.001 \\
\hline \multirow{2}{*}{$\begin{array}{c}\text { PROB SCORE } \\
\text { Problem Solving Strategies) }\end{array}$} & Pearson correlation & $0.216^{*}$ & 1 & $0.627^{* *}$ \\
\cline { 2 - 5 } & p-value & 0.030 & - & 0.000 \\
\hline \multirow{2}{*}{$\begin{array}{c}\text { SUPSCORE } \\
\text { (Support Reading } \\
\text { Strategies) }\end{array}$} & Pearson correlation & $319 * *$ & $0.627^{* *}$ & 1 \\
\cline { 2 - 5 } & p-value & 0.001 & 0.000 & - \\
\hline
\end{tabular}

$* *$ Correlation is significant at the 0.01 level (2-tailed).

*Correlation is significant at the 0.05 level (2-tailed).

Table-II represents that GLOB and PROB Score shows positive correlation with 0.216 coefficients of Pearson correlation and $p$-value 0.030 shows significant correlation. GLOB and SUB Score shows positive correlation with 0.319 coefficients of Pearson correlation and $p$-value 0.001 shows significant correlation. PROB and SUP Score shows positive correlation with 0.627 coefficient of Pearson correlation and $p$-value $<0.0001$ shows highly significant correlation. 
Table-III: Correlations between Metacognition score and academic achievement.

\begin{tabular}{|c|c|c|c|}
\hline \multirow{2}{*}{ Final Marks } & Final Marks & Total Score \\
\cline { 2 - 4 } & Pearson Correlation & 1 & $.372^{* *}$ \\
\cline { 2 - 4 } Total Score & Sig. (2-tailed) & - & .000 \\
\cline { 2 - 4 } & Pearson Correlation & $.372^{* *}$ & 1 \\
\cline { 2 - 4 } & Sig. (2-tailed) & .000 & - \\
\hline & $* *$. Correlation is significant at the 0.01 level (2-tailed). \\
\hline
\end{tabular}

Table-IV: Descriptive Statistics of Gender and academic achievement for metacognitive awareness of reading strategies.

\begin{tabular}{|c|c|c|c|c|c|}
\hline \multicolumn{2}{|c|}{ Metacognitive Sub Scale } & \multicolumn{2}{|c|}{ GLOB } & \multirow[t]{2}{*}{ SUP } & \multirow[t]{2}{*}{ PROB } \\
\hline \multirow{6}{*}{ Gender } & \multirow[t]{3}{*}{ Male } & $\mathrm{N}$ & 60 & & \\
\hline & & Mean & 3.85 & 3.80 & 3.91 \\
\hline & & SD & 0.37 & 0.35 & 0.38 \\
\hline & \multirow{3}{*}{ Female } & $\mathrm{N}$ & 41 & & \\
\hline & & Mean & 3.94 & 3.92 & 3.93 \\
\hline & & SD & 0.22 & 0.38 & 0.35 \\
\hline \multirow{9}{*}{$\begin{array}{c}\text { Academic } \\
\text { achievement }\end{array}$} & \multirow{3}{*}{ Low } & $\mathrm{n}=6$ & & & \\
\hline & & Mean & 3.82 & 3.75 & 3.87 \\
\hline & & SD & 0.56 & 0.41 & 0.46 \\
\hline & \multirow{3}{*}{ Moderate } & $\mathrm{n}=86$ & & & \\
\hline & & Mean & 3.90 & 3.87 & 3.91 \\
\hline & & SD & 0.28 & 0.37 & 0.36 \\
\hline & \multirow{3}{*}{ High } & $n=9$ & & & \\
\hline & & Mean & 4.05 & 4 & 4.07 \\
\hline & & SD & 0.08 & 0.34 & 0.33 \\
\hline
\end{tabular}

GLOB $=$ Global Reading Strategies

PROB $=$ Problem Solving Strategies

SUP $=$ Supportive reading strategies

In (Table-III) Correlation coefficient 0.372 between final marks of students and Metacognitive score shows positive correlation which mean that students who have high marks will show high MARSI score.

Table-IV describes the descriptive statistics of Gender and academic achievement level. Mean values of metacognitive scores shows that mean score of female is greater than male while academic achievement level show as the level increases the metacognitive awareness of reading strategies mean score increase. No significant difference was found level wise Academic achievement in GLOB, PROB and SUP mean score.

\section{DISCUSSION:}

In the burgeoning world of medical education, the task of educators is to mould medical students to be flexible thinkers, agile learners and competent doctors. Good metacognitive awareness is a necessity to attain these goals and is a skill that can be honed and developed to maximally utilize their intelligence. Metacognition is a complex phenomenon and past researches have great debate on the relationship of academic achievement and metacognition abilities. We have hypothesized that metacognition has a relationship with total marks of students (Predictor of academic achievement) obtained in their last professional 
examination held by university of health sciences as described in (table-III).

Researches state that medical students have higher levels of metacognitive abilities and academic achievement than non medical or other professional colleagues ${ }^{[14,15]}$. Students who have high metacognition score are more organized, good planners, and complete tasks on time. They develop skills and attitude that make them more proficient in their academic career $^{[16]}$.

Our study proved that academic performance and metacognitive score are significantly related. Similar findings reported in another study conducted at Lahore ${ }^{[17]}$. Another study established that a strong and positive relationship exists between metacognitive pathway of learning and academic performance of Indian medical students ${ }^{[18] .}$ These findings have been controlled by age, gender and intellectual ability ${ }^{[19]}$. According to Amzil, the group of students who got metacognition skills training achieves high scores than others ${ }^{[20]}$ . Among students metacognitive skills correlated strongly with performance ${ }^{[21]}$. Some authors have argued that metacognitive awareness is more related to performance than intelligence ${ }^{[22,23]}$.

Our study found that female medical students have better MARSI scores and this is confirmed in other studies ${ }^{[24]}$. In contrast to our result another study of 100 undergraduate students could not find significant difference in metacognitive awareness of female and male students ${ }^{[25]}$.

\section{CONCLUSION:}

Estimating meta-cognition in medical students is challenging because of the complexities involved in human learning. Our study found that these three dimensions of metacognition are inter related with each other and predictors of metacognition and good academic performance. Teachers should be trained about metacognitive strategies in the classroom so that medical undergraduates can perform better academically.

ACKNOWLEDGMENT: None.
CONFLICT OF INTEREST: All authors

disclose no conflict of interest.

GRANT SUPPORT \& FINANCIAL DISCLOSURES: None.

\section{REFERENCES:}

1. Rhodes MG. Metacognition. Teaching of Psychology. 2019;46(2):168-175 DOI: $10.1177 / 0098628319834381$

2. Flavell JH. Metacognition and cognitive monitoring: A new area of cognitive-developmental inquiry. American psychologist. 1979;34(10):906. DOI:10.1037/0003-066X.34.10.906.

3. Meniado JC. Metacognitive Reading Strategies, Motivation, and Reading Comprehension Performance of Saudi EFL Students. English Language Teaching. 2016;9(3):117-29. DOI.10.5539/elt. v9n3p117

4. Barati M, Joo SB, Aria AM. The effect of metacognitive beliefs and self-regulation strategies on students' academic motivation. Journal of Social Sciences and Humanities Research. 2018;6(01):19-23. DOI: 10.24200/jsshr.vol6iss01pp19-23.

5. Pressley M, Afflerbach P. Verbal protocols of reading: The nature of constructively responsive reading. New York: Routledge; 1995.

6. Snow CE, Burns SM, Griffin P. Predictors of success and failure in reading. Preventing reading difficulties in young children. 1998:137-171.

7. Boyraz S, Altinsoy E. Metacognitive awareness of reading strategies in EFL context. International Journal of Language Academy. 2017;5(5):159-167.Doi: 10.18033/ijla.3655

8. Ghaith G, El-Sanyoura H. Reading comprehension: The mediating role of metacognitive strategies.2019;31(1):1943. [Available from]: http://nflrc. hawaii.edu/rfl/April2019/April2019/article s/ghaith.pdf

9. Abdellah R. Metacognitive Awareness and its Relation to Academic Achievement and Teaching Performance of Pre-service Female Teachers in Ajman University in 
UAE. Procedia Social and Behavioral Sciences. 2015;174:560-567. DOI:10. 1016/ j.sbspro.2015.01.707

10. Jain D, Tiwari GK, Awasthi ID. Impact of metacognitive awareness on academic adjustment and academic outcome of the students. International Journal of Image Processing. 2017;5(1):123-38. DOI: 10.25215/0501.034

11. Mokhtari K, Reichard CA. Assessing Students' Metacognitive Awareness of Reading Strategies. Journal of Educational Psychology, 2002:94(2): 249-259. DOI:10.1037/0022-0663.94.2.249.

12. Hong-Nam K, Leavell AG. Reading strategy instruction, metacognitive awareness, and self-perception of striving college developmental reader. Journal of College Literacy and Learning. 2011;37:3-17. [Available from]: https://www.jcll.org/volume-37-2011

13. Karbalaei A. A comparison of the metacognitive reading strategies used by EFL and ESL readers. The Reading Matrix. 2010;10(2):165-180. [Available from]: http://www.readingmatrix.com/articles/se pt_2010/alireza_karbalaei.pdf

14. Ohtani K, Hisasaka T. Beyond intelligence: A meta-analytic review of the relationship among metacognition, intelligence, and academic performance. Metacogniation and Learning .2018;13(2):179-212. DOI: $10.1007 / \mathrm{s} 11409-018-9183-8$

15. Saeedzadeh M, Raeisoon MR, Mohammadi Y. The relationship between cognitive and metacognitive strategies and academic achievement of students of Birjand University of Medical Sciences. Future of medical education journal. 2018;8(1):2730.

16. Panchu P, Bahuleyan B, Seethalakshmi K, Thomas $\mathrm{T}$. The role of metacognitive awareness of reading strategies as a predictor of academic achievement. World journal of Medical Education and Research. 2016;12(1):10-15.

17. Iqbal S, Akram R, Gohar B, Mahmood A, Naz N, Mudasar S. Metacognitive Awareness and Academic Achievement of Medical Students in Different Medical Colleges of Lahore, Pakistan . International Journal of Contemporary Medical Research.
2019;6(9):I4-I8. DOI: $10.21276 / \mathrm{ijcmr}$. 2019.6.9.32.

18. Mishra BN, Panwar NK, Barjatya P, Chouhan DS, Mohapatna SC. An age and genderbased analysis of 'Metacognitive Awareness Inventory'(MCAI) among firstyear MBBS students from a Central Indian medical college. The Journal of Community Health Management. 2019;6(3):77-81. DOI: $10.18231 / j . j c h m .2019 .018$

19. Baradaran HR, Shajari J, AlirezaeeTehrani S. An assessment of the relationship between the meta-cognitive awareness of reading strategies and students' achievement in Iran University of Medical Sciences in 2012-2013. The Journal of Medical Education and Development. 2014;9(2):2-13.

20. Amzil A. The Effect of a Metacognitive Intervention on College Students' Reading Performance and Metacognitive Skills. Journal of Educational and Developmental Psychology. 2013;4:27-45. DOI:10.5539/ jedp.v4n1p27

21. Khan MJ, Rasheed S. Moderating role of learning strategies between metacognitive awareness and study habits among university students. Pakistan Journal of Psychological Research.2019; 31:215-231. DOI:10.33824/PJPR. 2019. 34.1 .12

22. Ohtani K, Hisasaka T. Beyond intelligence: A meta-analytic review of the relationship among metacognition, intelligence, and academic performance. Metacognition and Learning. 2018 13(2):179-212. DOI:10. 1007/s11409-018-9183-8

23. Sadipour I, Ghavam SE, Farrokhi N, Assadzadeh $\mathrm{H}$, Sameti N. Investigating the Mediating Role of Learning Strategies (Cognitive and Metacognitive) between Emotional Intelligence and Academic Performance among Students of Smart and Ordinary School. International Electronic Journal of Mathematics Education. 2017;12(3):409-420.

24. Yokuşoğlu Ç, Atasoy $M$, Tekeli N, Ural A, Ulus Ç, Taylan Y, Aydin G, Gültekin G, Emül M. A Survey Focusing on Lucid Dreaming, Metacognition, and Dream Anxiety in Medical Students. Archives of Neuropsychiatry. 2017;54(3):255-259. 
DOI: $10.5152 /$ npa.2017.12606

25. Sawhney N, Bansal S. Metacognitive awareness of undergraduate students in relation to their academic achievement. International Journal of Indian Psychology. 2015;3(1):107-114. DOI:10.25215/ 0301.136

\section{Authors' Contribution:}

Subhan Ullah: Research conception and design of study.

Sami Ullah: Data analysis and interpretation of data.
Khalid Parvez: Final approval of manuscript and proof reading.

Ghulam Abbas Sheikh: Revising it critically for important intellectual content. 